\title{
Assessing the determinants of Ebola Virus Disease Transmission in Baka Community of the Tropical Rainforest of Cameroon
}

Frankline Sevidzem Wirsiy

Faculty of Science, University of Buea

Alphonse Um Bock

FAIRMED Yaounde

Jane-Francis Kihla Tatah Akoachere ( $\nabla$ jakoachere@yahoo.com )

University of Buea

Research article

Keywords: Ebola Virus Disease, Knowledge, Practices, Determinants, Misconceptions, Transmission, Cameroon

Posted Date: May 5th, 2020

DOI: https://doi.org/10.21203/rs.2.17889/v2

License: (c) (i) This work is licensed under a Creative Commons Attribution 4.0 International License. Read Full License

Version of Record: A version of this preprint was published at BMC Infectious Diseases on April 7th, 2021. See the published version at https://doi.org/10.1186/s12879-021-06011-z. 


\section{Abstract}

Background: Ebola virus disease (EVD) is a severe, often fatal illness in humans and nonhuman primates caused by the Ebola virus. Treatment and vaccine are under development, hence prevention is paramount. Design of effective prevention interventions requires an understanding of the factors that expose communities at risk. It was based on this that we investigated the Baka community of AbongMbang Health District in tropical rain forest of Cameroon.

Methods : A cross-sectional study was conducted with participants randomly selected from 13 villages in Abong-Mbang by multi-stage cluster sampling. A questionnaire was administered to them to collect demographic information, data on knowledge of EVD, their feeding and health-seeking behaviour. Data was analyzed using the chi-square test. Knowledge of EVD was assessed using an 8 item Morisky Scale. An adapted Threat Capability Basic Risk Assessment Guide was used to determine their risk of exposure to infection.

Results: A total of 510 participants, most of whom were hunters (31.4\%), farmers (29.8\%), and had primary education (62.7\%), were included in this study. Although $83.3 \%$ participants had heard of EVD, most (71\%) did not know its cause. Their source of information was mainly informal discussions in the community (49\%). Misconceptions were identified with regards to knowledge on the cause and mode of transmission. Only $43.1 \%$ accepted EVD could be transmitted from human-to-human. Generally, participants' knowledge of EVD was poor. Demographic factors such as level of education, occupation and ethnic group significantly affected knowledge of EVD. The majority of participants were at a very high risk of exposure to infection as they consumed various forms of bush meat and were involved in other risky practices such as scarification and touching of corpses. Although over half of participants seek medical care, most of them preferred traditional medicine. Socio-cultural and service-related factors were deterrent factors to medical care.

Conclusion: Participants generally had poor knowledge of EVD and were at high risk of to infection. We recommend rigorous sensitization campaigns in study area to educate the population on EVD and clarify the misconceptions identified. EVD surveillance is recommended particularly as outbreaks have often been reported in the Congo Basin.

\section{Background}

Ebola virus disease (EVD) is a fatal illness affecting humans and nonhuman primates caused by the Ebola virus, a member of the family Filoviridae. The disease begins with flu-like symptoms. Haemorrhagic symptoms usually appear late resulting in delayed diagnosis [1]. There is an increasing evidence of asymptomatic infections [2-4]. Outbreaks have been caused by four of the six species of the Ebola virus: Zaire, Bundibugyo, Taï Forest and Sudan [5]. The Ebola virus was discovered during simultaneous outbreaks of febrile illness with shock and hemorrhage in Sudan and Democratic Republic of Congo-DRC (former Zaire) in 1976 [6]. Since then, over 25 outbreaks have been reported in Africa, with most of them 
occurring in the Congo Basin [7]. The largest and deadliest outbreak ever registered occurred in 2014 and was caused by the Zaire Ebola virus. It resulted in a very high case-fatality ratio of up to $90 \%$ [8]. The Ebola virus has largely circulated in sub-Saharan Africa causing dreadful epidemics of EVD [7]. Following the West African outbreak in 2014, it has become a global public health security threat [9].

Fruit bats (Pteropodidae family) have been identified as the reservoir of Ebola virus [10] though there is a possibility that other animals could also harbour the pathogen. Studies have demonstrated the Zaire Ebola virus to replicate in pigs [11] and there is evidence of transmission from pigs without direct contact [12] indicating that pigs should be considered a potential amplifier host during outbreaks of EVD. No other domestic animal has been shown to have an association with filovirus outbreak. Spread of infection to humans (primary transmission) occurs by the spillover effect, following contact with blood, secretions, organs and bodily fluids of an infected reservoir or an infected non-human primate [8, 13-15]. Person-to-person transmission (secondary transmission) occurs in the community following contact with blood, secretions or other bodily fluids of individuals infected, EVD patients or individuals who have died of Ebola. Healthcare workers in close contact with an Ebola patient without using appropriate infection control measures and adequate barrier procedures have been infected while treating patients [16]. Ebola virus can survive in liquid or dry material for days [17] facilitating transmission by fomites.

Many factors increase the risk of acquiring and transmitting the Ebola virus [18]. Social conditions such as human mobility, behavioural and cultural practices, bushmeat consumption, burial practices, preference for traditional medicines and cures, and fear and obstruction of health interventions have greatly enabled and enhanced human to human transmission $[14,19]$.

As at the time of 2014 outbreak, there was no licensed treatment or vaccine for EVD. Patients are only given symptomatic treatment which when administered early can improve the chances of recovery [20]. Recently, the U.S. Food and Drug Administration (FDA) approved the Ebola vaccine rVSV-ZEBOV, a single dose vaccine that offers prevention against the Zaire ebolavirus species [21]. Prevention and control measures of an outbreak of EVD had aimed at interrupting transmission. This is largely through avoidance of practices that predispose to infection [14]. For these measures to be successful there is a need for an understanding and avoidance of the risky behaviours of a community.

EVD epidemics have been reported in some countries that border Cameroon [22]. Although the disease has never been reported, there is serologic evidence of Ebola virus in Cameroon $[4,23,24]$ with highest rates of seropositivity among the pygmies (Baka people) and rain forest farmers [23]. In a large scale survey of non-human primates across Central Africa, Leroy et al. [25] reported serologic evidence of exposure to Ebola infection in Chimpanzees in Cameroon. These findings confirm exposure to the Ebola virus and show that a less-virulent virus could be circulating in Cameroon, accounting for the absence of human cases and/or observed epizootics. The Southeastern equatorial rain forest of Cameroon harbours fruitbats which are reservoirs of the Ebola virus, as well as animals susceptible to the Ebola virus disease [26]. Being that this is part of the tropical rainforest of the Congo Basin; inhabitants of this area are at a high risk of exposure to the virus. In addition, studies have revealed a high exposure to non-human 
primates in Cameroon [27]. A larger investment is needed for containing rather than preventing an Ebola virus disease outbreak; prevention is therefore mandatory in areas at risk such as the rainforest of Cameroon. For prevention to be effective there is need for data to guide the design of health promotion interventions. It was against this background that we assessed the risk of exposure of the Baka community of Abong-Mbang Health District, South Eastern Cameroon to the Ebola virus infection by investigating their knowledge on EVD and practices that could expose them to infection.

\section{Methods}

\section{Study design and setting}

This was a community based cross-sectional descriptive study carried out in the Abong-Mbang Health District, Upper Nyong Division of East Cameroon. The Abong-Mbang Health District is located in the south eastern rain forest of Cameroon which is part of the rainforest of Central Africa, where most Ebola virus disease outbreaks except the 2014 West African outbreak originated [7, 28].

The Abong-Mbang has an estimated population of about 28,904 inhabitants and covers an area of about $15.000 \mathrm{~km}^{2}$. It is made of 92 villages that are grouped into 8 health areas, Mindourou, Nkouak, Mbomba, Angossas, Ankoung, Atok, Abong-Mbang North and Abong-Mbang South (Fig. 1) [29] and has 25 public and private health facilities. It has a wet equatorial climate (also known as a Guinea type climate). Its forest has abundant and diverse animal life with animals such as monkeys, some of the last populations of gorillas and chimpanzees [28]. Fruit and insectivorous bats and birds of various species are also common, as are various rodents.

Figure 1: Map of Abong-Mbang Health District showing various health areas

Source: [29]

\section{Study Population}

The study population comprised of the Baka community of Abong-Mbang Health District. The Baka people (formerly called the Pygmies) are an ethnic group inhabiting the southeastern rain forests of Cameroon, northern Republic of the Congo, northern Gabon, and southwestern Central African Republic and Western Equatorial state of South Sudan. The Baka community of Abong-Mbang Health District is made up of 24 villages: Ampele, Andoa, Aviaton, Bitsoman, Cyrie, Djibot, Dympam, Diassa, Elandjoh, Kendjo, Madouaite, Mapela, Mayos, Mballam, Mbang, Mbiatoh, Mengang, Menzoh, Missoume, Moangong, Nombakele, Petit Paris, Plateau and Sombou. Out of the 24 villages in Abong-Mbang, our study involved 13 villages. A small proportion of Bantu people also reside in this area. Almost the entire Baka population is semi-sedentarised, spending part of the year in their roadside settlements and go for short- and long-term (up to several months) hunting and gathering expeditions deep into the forest. Most of them rely almost exclusively on traditional health care [30]. 


\section{Inclusion and Exclusion Criteria}

Individuals aged $\geq 18$ years who have resided for at least 5 years in the Baka community of AbongMbang Health District, and who granted consent to participate in the study were recruited. Those who denied consent/assent, were $<18$ years old or had lived in the community for less than 5 years were excluded.

\section{Sampling and sample size determination}

A multi-stage cluster sampling technique was used. Of the 24 villages of the Baka community 13 were randomly selected. From each of these villages, household heads or their representatives were recruited by systematic random sampling.

[Please see the supplementary files section to view the equations.]

\section{Sample collection and analyses}

Data was collected by trained research assistants using a pre-tested semi-structured questionnaire adapted from the risk factors involved in the Health Promotion Theory and then developed according to the objectives of the study. The questionnaire was divided into four sections: demographics, an assessment of participants' knowledge on Ebola, their feeding habits and practices, and their health seeking behavior as contributory factors to exposure to Ebola.

Data was entered into EPI Info 7, cleaned and analyzed using SPSS version 20.0. The relationship between the study outcome and the independent variable was analyzed using the chi-square test. An adapted 8 item Morisky Scale was used to assess level of knowledge of the symptoms and transmission of Ebola. Participants who could list 4-8 correct manifestations or routes of transmission were considered to have good knowledge; those with 2-3 correct manifestations had fair knowledge and those who had one or none correct had poor knowledge.

An adapted Threat Capability Basic Risk Assessment Guide [31] was used to assess the level of risk involved in consuming bush meat. This guide had four different levels of assessment: very high, high, moderate and low. Participants who consumed all six animals listed (Fruit bats, chimpanzees, gorillas, bush pigs, monkeys, forest Antelopes, and Porcupines) were considered to be at a very high risk, 4-5 animals at high risk, 2-3 animals at moderate risk and 0-1 animal at low risk.

\section{Ethical considerations}

Ethical approval was obtained from the Centre Regional Ethics Committee for Human Health Research ( $N^{\circ}$ : CE031/CRERSHC) of the Ministry of Public Health, Cameroon. Administrative approval was obtained from the Regional Delegation of Public Health for the East Region. Informed consent was obtained from every participant prior to collection of data. Participants 21 years and above granted consent to participate in the study. For those $<21$ years old, consent was obtained from their parent/guardians. 
Interviews were conducted in private. Questionnaires were assigned codes instead of writing the name of the participants. The original questionnaire which was in English was translated to French. Data collectors were French speaking with three of them also serving as translators as they could speak the Baka language.

\section{Results}

Characteristics of Study Population A total of 510 individuals participated in this study. Males (49.6\%) and females (50.4\%) were almost of the same proportion. Participants were from two ethnic groups: Baka (68\%) and the Bantu (32\%). The majority were natives of the study area (96.5\%), had primary level of education (62.7\%), aged 18-25 years (32.2\%), married (73.5\%), hunters (31.4\%) and had 1-5 children (72.5\%) (Table 1).

\section{Knowledge of Ebola and relationship with demographic characteristics of participants}

Four hundred and twenty-five (83.3\%) participants had heard about Ebola. Their sources of information were: discussions among community members (49\%), radio (38\%), television (10\%) and health talk (3\%) (Fig. 2a).There was no significant difference in the level of awareness of participants on Ebola with respect to ethnic group $\left(X^{2}=2.469 P=0.116\right)$, gender $\left(X^{2}=1.319 \quad P=0.251\right)$ and age $\left(X^{2}=6.418 \quad P=\right.$ $0.170)$. Significant differences were observed with respect to level of education $\left(\chi^{2}=408.00 P<0.05\right)$ and occupation $\left(\chi^{2}=483.474, P<0.05\right)$ (Table 2$)$.

Figure 2: Participants' knowledge on EVD (a) Sources of information of study participants (b) Opinion on causes of EVD; (c) Modes of Transmission(d) Manifestations encountered by participants (e) Level of knowledge on means of EVD Transmission ( $f$ ) Level of knowledge of manifestations of Ebola

Out of the 425 respondents who had heard of Ebola, 234 (55.1\%) reported that they knew its cause. The majority $(29 \%)$ of them reported a virus as the causative agent. Other causes reported were animal (25\%), dead animal (14\%), witchcraft (15\%) and curse (17\%) (Fig. 2b). There were significant differences in level of knowledge on causes of Ebola with respect to ethnic group ( $\left.X^{2}=44.270 \quad P<0.05\right)$, level of education $\left(X^{2}=170.848 P<0.05\right)$ and occupation $\left(X^{2}=271.534, P<0.05\right)$ (Table 2$)$.

Only $183(43.1 \%)$ of the 425 participants who had heard of Ebola believed that it could be transmitted from person to person. One hundred and forty-six (34.4\%) denied the possibility of human to human transmission while the remaining $96(22.6 \%)$ had no idea of transmission. Contact with an infected person (21.8\%) was the mode of transmission reported by most participants (Fig. 2c). Other modes of transmission reported were: eating contaminated food (16.4\%), water (14.8\%), respiration (11.5\%), smoking cigarette (9.8\%), witchcraft/spirit (8.2\%) and flies (6\%) (Fig. 2c). The majority of participants (49\%) had poor knowledge on transmission of Ebola disease (Fig. 2d). Ethnic group $\left(X^{2}=30.751 \quad P<\right.$ 
0.05), level of education $\left(X^{2}=381.370, P<0.05\right)$ and occupation $\left(X^{2}=644.521, P<0.05\right)$ showed significant differences with respect to knowledge on the modes on transmission of Ebola (Table 2).

With regards to manifestations of EVD, bloody diarrhea, fever and vomiting were the symptoms most reported (38.3\%) (Fig. 2d). Participants who reported these symptoms were mainly traditional healers and they indicated some patients with such manifestations had come to their shrine for consultation. Other participants saw similar symptoms in the health center. One man reported he came across a patient, vomiting blood with hiccups at a hospital in Bertoua and it was rumoured the patient was suffering from Ebola hemorrhagic fever. Some respondents reported they lost a relative who had suffered from bloody diarrhea and high fever for 1-2 weeks. Among the respondents who had heard about Ebola, 11\% (47) had come across a person suffering from at least one of the manifestations listed and $5.3 \%$ indicated that the manifestations were common in the community. Based on the Morisky Scale the majority of participants $(44 \%)$ had poor knowledge of the symptoms of Ebola (Fig. 2f).

\section{Feeding Behaviour}

Consumption of bushmeat was a common practice among respondents as 506 (99.2\%) consumed bush meat. Animals mostly consumed were fruit bats, chimpanzees, gorillas, bush pig, monkeys, forest antelope and porcupines. Based on level of risk of exposure to infection, $40.7 \%, 29.6 \%, 24.9 \%$ and $4.7 \%$ of participants respectively were considered to be at a very high risk, high risk, moderate risk and low risk of exposure (Fig. 3a). Participants consumed fresh cooked meat (38.7\%) or dry cooked meat (31.8\%), however, $14.4 \%$ consumed fresh uncooked meat (Fig.3b). The meat was mostly hunted (57.7\%). Some respondents (22.1\%) consumed dead animals recovered from the forest (Fig. 3c). As the underlying risk of exposure to an infection with Ebola virus is on the person who prepares the meat due to direct contact with the blood/body fluid of the animal, based on our investigation meat preparation was done mainly women (wives of the male respondents ) (33\%) (Fig. 3d).

Figure 3: Feeding behaviour of participants: (a) Risk of exposure of participants to Ebola of meat consumed (c) Source of meat (d) Person preparing the meat

\section{Health-Seeking Behaviour}

The health seeking behavior of participants was investigated to highlight its role on the spread of the Ebola virus (Fig. 4). Factors influencing health seeking behavior such as sociocultural and service-related factors were investigated. Sociocultural factors included beliefs about illness etiologies and trajectories, treatment strategies (scarifications), treatment preferences (medical treatment, traditional healer and selfcare), and characteristics of the individuals engaged in health seeking (level of education, poverty status). The majority of respondents (54.1\%) sought health care in a medical facility when sick. However, $36.7 \%$ and $9.2 \%$ consulted traditional healers and provided self-care respectively (Fig. 4a). 
Figure 4: Health seeking behaviour of participants (a)Treatment preferences of study participants (b) Reasons for scarification (c) Reasons for not seeking medical care in the health facility (d) Distance to health facility from place of residence

Three hundred and fifty-seven (70\%) respondents had been scarified. Scarifications were performed mainly for traditional treatment (49\%), spiritual protection (29\%) and for aesthetic reasons (10\%) (Fig. 4b). Of the 234 respondents who did not seek medical treatment when sick, about half of them $(50.4 \%)$ indicated financial constraints as a deterrent factor (Fig. 4c). Other major reasons advanced were inaccessibility of health care facility (32.5\%), and belief in traditional medicine (15.8\%). However, the majority of respondents $(91.6 \%)$ indicated they had no health facility in their village of residence. Thirtyfour percent $(34 \%)$, of participants travelled a distance of $6-10 \mathrm{~km}$, to get to a health facility while only few $(21 \%)$ covered $\leq 5 \mathrm{~km}$. The rest covered distances $\geq 11 \mathrm{~km}$ to get to a health facility (Fig. $4 \mathrm{~d}$ ).

The attitude of health personnel towards respondents and the functionality of the health facility were also discouraging factors to seeking medical treatment. Participants reported they were at times ignored by the health staff because of their social and poverty status. Thus the intrusive nature of the health staff towards these individuals was a potential contribution to them not seeking medical treatment. In one of the villages, the health center had not been functional for the 3-4 years prior to this study due to lack of equipment and staff.

\section{Discussion}

EVD outbreaks constitute a major public health concern not only in sub-Saharan Africa but has become a global threat $[9,30]$. Since the first epidemic of Ebola that was reported in 1976, globally, there have been over 36 documented outbreaks (19 major outbreaks and 17 minor) [31]. The largest outbreak lasted from 2014 to 2016 in West Africa and resulted in 28,646 cases and 11,323 deaths [32]. At the time of this study, there was an ongoing outbreak of Ebola in DRC with increasing number of cases [33] and it extended to Uganda [34].To minimize the chances of an outbreak in areas at risk such as the Baka community, knowledge on factors that could predispose inhabitants to infection is necessary. WHO aims to prevent Ebola outbreaks by maintaining surveillance for EVD and supporting at-risk countries to develop preparedness plan. Prevention can only be successful following an understanding of the potential risk factors as this will be useful to develop intervention measures targeting communities at risk. It was against this background that this study was carried out in the Baka community.

Most participants (83.3\%) had heard of Ebola virus disease. The level of awareness in our study was lower than $96 \%$ reported in Guinnea [35] and $88 \%$ in Sokoto, Nigeria [36]. These studies and ours were conducted during the West African EVD outbreak explaining the high level of awareness. Compared to other countries where information on the disease was obtained mainly through mass media [37, 38], in our study, participants learned of the disease mainly from discussions in the community. Health talk source reported by a very small proportion (3\%) of participants. This is disturbing as informal discussions in a community with such a low level of education as observed in the Baka community could have far 
reaching consequences as wrong information could be circulated such that in the event of an outbreak of EVD such information may contribute to more exposures to infection. Proper education of inhabitants of the Baka community through health talk is therefore very important. Radio signals are widely captured in the study area, explaining why radio (38\%) was another main source of information. Those who had heard about Ebola through television (10\%) were individuals who had visited the urban areas as television signals were poor in the villages studied. With regards to symptoms, bloody diarrhea, fever and vomiting were the symptoms reported by most of our participants. Evaluating the level of knowledge of symptoms, only $21 \%$ of participants had good knowledge. This indicates the need for an intensive sensitization campaign in the study area, particularly as the EVD has often been reported in some countries in the Congo Basin. Proper education of inhabitants in an area at risk such as the Baka community through health talks is very important as these are given by individuals who are well informed about the disease. Among participants who had heard of Ebola $(n=425,83.3 \%)$, slightly more than half of them reported they knew the cause of the disease of which only $29 \%$ stated a virus as the cause. This is not surprising because with the low level of education of participants, they could easily remember the factors that facilitate transmission such as animal or dead animal instead of the virus as the cause of EVD. Based on our study, participants' knowledge on the cause, transmission and manifestation of EVD was poor.

There were misconceptions on the cause and transmission of the disease. Some participants attributed the disease to a curse or witchcraft. With regards to misconception on the mode of transmission up to $34.1 \%$ of participants denied the possibility of human-to-human transmission of EVD. Some participants attributed transmission to respiration, eating contaminated food, smoking cigarette, water and flies. Similar misconceptions have been reported in areas with an Ebola outbreak $[35,38,39]$ and underscore the need for intensive health promotion efforts in this community particularly as only $33 \%$ had good knowledge of transmission.

Studies have shown some ethnic backgrounds to be an important risk factor influencing exposure to Ebola virus in many communities [23]. Cultural beliefs and behaviours have accounted for the persistence of outbreaks as they counter prevention and control measures [18, 40-42]. We investigated the feeding behavior and health seeking behavior of the inhabitants of the Baka community to understand how they could contribute to exposure to Ebola virus infection. Bush meat hunting and consumption was a common practice among inhabitants with some consuming uncooked fresh meat. Hunting is not only for domestic use but is also an income generating activity in the study area. As previous reports have shown evidence of Ebola virus infection in some of the animals consumed [24], these are practices that could expose them to EVD if the strain in circulation is virulent. The majority of participants (40.7\%) were considered to be at a very high risk of exposure to infection. Bush meat handling, preparation and consumption has been recognized as an important contributor to the spillover effect in areas that have witnessed an outbreak of Ebola [14,15]. Despite this high exposure, no case of Ebola virus disease has been documented in Cameroon though there are reports on evidence of infection in humans [22,43,44]. These studies reported highest rates of infection among pygmies, young adults, and rainforest farmers 
[22]. This shows that a less virulent strain might have circulated in study area and could not cause any clinical disease.

The health seeking behaviour was investigated to highlight its role in the secondary transmission of infection. Although more than half of the participants (54.1\%) reported they seek medical treatment when ill, a significant proportion (32.5\%) relied on traditional medicine and self-care (9.2\%). Studies in areas that have witnessed an outbreak of Ebola $[37,38]$ have reported higher proportions of participants seeking medical care if they fall ill. This is because they must have received health promotion messages which emphasized the importance of medical care. The Baka are renowned for traditional healing [45]. In our study, $70 \%$ of participants had undergone scarification which was performed for treatment purposes. Other major reasons for scarification were spiritual protection, customary practice and beauty enhancement. In case of an outbreak, practices such as scarification could play a major role in secondary transmission of EVD. This is because with their low level of education, traditional healers may have limited knowledge on infection prevention and may instead expose their patients to infection. The semisedentary lifestyle of the Baka people influenced their ability to seek medical treatment in a health facility particularly if it is at a distant location. Poverty, health care accessibility and functionality were the major contributory factors. Up to $91.2 \%$ of study participants indicated they did not have a health facility in their village of residence. In one of the villages, the Health Centre is present but had not been functional for some years due to lack of equipment and staff. Some participants complained of the attitude of some medical staff who at times ignored them because of their social and economic status. This greatly discouraged them from subsequent visits.

\section{Limitations}

Our study did not complement the quantitative data with sufficient qualitative data to capture more information on knowledge, practices and predisposing factors to Ebola virus infection and spread. In addition, the design of the questionnaire limited the amount of data that was collected on knowledge and behavioural practices that could influence exposure.

\section{Conclusion}

Although the majority of the Baka community was aware of the EVD, their knowledge on its cause and transmission was poor. Most participants had misconceptions about Ebola and were engaged in practices that could expose them to infection with the Ebola virus. Based on our findings there is need for rigorous sensitization to educate people about Ebola and clarify the misconceptions observed among participants. Surveillance of communities in study area for EVD is recommended particularly as outbreaks of EVD have often been reported in the Congo Basin. There is an urgent need for more functional medical facilities in study area for prompt disease diagnosis and management.

\section{List Of Abbreviations}


CDC: Centers for Disease Control and Prevention

DRC - Democratic Republic of Congo

EVD - Ebola virus disease

EV - Ebola virus

WHO - World Health Organization

\section{Declarations}

\section{Ethics approval and consent to participate}

All the principles of a good ethical research were respected. Ethical approval ( $N^{\circ}$ : CE031/CRERSHC) was obtained from the Centre Regional Ethics Committee for Human Health Research of the Ministry of Public Health Cameroon. Participants 21 years and above granted consent to participate in the study. For those $<21$ years old, consent was obtained from their parent/guardians.

\section{Consent for publication}

Not applicable

\section{Availability of data and material}

Not applicable

\section{Competing interests}

The authors declare that they have no competing interests.

\section{Funding}

We received support from FAIRMED Africa

\section{Authors' contributions}

WFS together with UBA and J-FKTA designed the study, WFS collected and analyzed data, UBA and JFKTA supervised the study, WFS and J-FKTA drafted the manuscript. All authors read and approved the final manuscript.

\section{Acknowledgements}

This study was funded by FAIRMED Africa. We thank our study participants and various authorities who granted authorization for this study to be conducted. 


\section{References}

1. Bannister B. Viral haemorrhagic fevers imported into non-endemic countries: risk assessment and management. Br Med Bull. 2010; 95:193-225.

2. Malangu S, Alfonso VH, Hoff NA, Doshi RH, Mulembakani P, Kisalu NK, Okitolonda-Wemakey E, Kebela BI, Marcus H, Shiloach J, Plue J-N, Wright LL, Muyembe-Tamfum J-J, Sullivan NJ, Rimoin AW. Serologic evidence of Ebola virus infection in a population with no history of outbreaks in the Democratic Republic of Congo. J Infect Dis. 2018; 217: 529-537

3. Racaniello V, Tuller D, Rey GU. Ebola virus infections but no outbreak. 2018. https://www.virology.ws/2018/02/22/nonlethal-ebolavirus-infections/. Accessed 2 Sept 2019.

4. Steffen I, Lu K, Yamakoy EO, Muyembe-Tamfum J-F, Ndembi N, Brennan CA, Hackett J, Stramer SL, Switzer WM, Saragosti S, Mbensa GO, Laperche S, Rimoin AW, Simmons G. Serologic prevalence of Ebola Virus in Equatorial Africa. Emerg Infect Dis. 2019; 25(5): 911-918

5. CDC. Ebola virus disease. 2018. https://www.cdc.gov>ebola>about. Accessed 2 Sept 2019

6. Brès P. The epidemic of Ebola haemorrhagic fever in Sudan and Zaire, 1976 (introductory note). Bull World Health Organ. 1978; 56:245.

7. History of Ebola virus disease. 2019. https://www.cdc.gov/vhf/ebola/history/chronology.html. Accessed 1 Sept 2019

8. Fomenty P. (2014). Ebola virus disease. Emerg Infect Di 2014. DOl:https://ds.doi.org/10.1016/B9780-12-416975-3.00009-1

9. Kalra S, Kelkar D, Galwankar SC, Papadimos TJ, Stawicki SP, Arquilla B, Hoey BA, Sharpe RP, Sabol D, Jahre The emergence of Ebola as a global health security threat: From 'lessons learned' to coordinated multilateral containment efforts. J Global Infect Dis. 2014; 6:164-77.

10. Pourrut X, Delicat A, Rollin PE, Ksiazek TG, Gonzalez JP, Leroy EM. Spatial and temporal patterns of Zaire ebola virus antibody prevalence in the possible reservoir bat species. J Infect. Dis. 2007; 196(Suppl 2): S176-183

11. Kobinger GP, Leung A, Neufeld J, Richardson JS, Falzarano D, Smith G, Tierney K, Patel A, Weingartl HM. Replication, pathogenicity, shedding, and transmission of Zaire ebola virus in pigs. J Infect Dis. 2011; 204: 200-208

12. Weingartl HM, Embury-Hyatt C, Nfon C, Leung A, Smith G, Kobinger G. Transmission of ebolavirus from pigs to non-human primates. Sci Rep. 2012; 2:811

13. Leroy EM, Epelboin A, Mondonge V, Pourrut X, Gonzalez J-P, Muyembe-Tamfum J-J, Formenty P. Human Ebola outbreak resulting from direct exposure to fruitbats in Luebo Democratic Republic of Congo, 2007. Vector Borne Zoonotic Dis. 2009; 9(6): 723-728

14. Alexander KA, Sanderson CE, Marathe M, Lewis BL, Rivers CM, Shaman J, Drake JM, Lofgren E, Dato VM, Eisenberg MC, Eubank S. What factors might have led to the emergence of Ebola in West Africa. 
PLoS Negl Trop Dis. 2015; 9 (6): e0003652

15. Rewar S, Mirdha D. Transmission of Ebola virus disease. An Overview. Ann Glob Health. 2014; 80 : 444-451

16. Selvaraj SA, Lee KE, Harrell M, Ivanov I, Allegranzi B. Infection rates and risk factors for infection among health workers during Ebola and Marburg virus outbreaks: a systematic review. J Infect Dis. 2018; 218(Suppl 5): S679-S689

17. Piercy TJ, Smither SJ, Steward JA, Eastaugh L, Lever MS. The survival of filoviruses in liquids, on solid substrates and in a dynamic aerosol. J Appl Microbiol. 2010; 109: 1531-9

18. Factors that contributed to undetected spread of the Ebola virus and impeded rapid containment.2015. https://www.who.int/csr/disease/ebola. Accessed 5 Sept 2019

19. Brainard J, Hooper L, Pond K, Edmunds K, Hunter PR. Risk factors for the transmission of Ebola or Marburg virus disease: a systematic review and meta-analysis. Int J Epidemiol. 2015; 45 (1):102-16

20. CDC. Ebola virus disease: prevention and vaccine.

https://www.cdc.gov/vhf/ebola/prevention/index.html Last updated November 2019

21. CDC. Ebola virus disease: treatment. https://www.cdc.gov/vhf/ebola/treatment/index.html Last updated November 2019

22. Awah PK. Ebola virus disease in Africa: a commentary on its history and local and global control. Pan Afr Med J. 2015; 22(Suppl 1): 18

23. Bauree P, Bergmann JF. Ebola virus infection in man: a serological and epidemiological survey in the Cameroon. Am J Trop Med Hyg. 1983; 32(6): 1465-1466.

24. Johnson ED, Gonzalez JP, Alain G. Filovirus activity among selected ethnic groups inhabiting the tropical forest of equatorial Africa. Trans R Soc Trop Med Hyg. 1994; 87(2): 536-538.

25. Leroy EM, Telfer P, Yaba P. A serological survey of Ebola virus infection in central African nonhuman primates. J Infect Dis. 2004; 190:1895 - 9.

26. WWF in Cameroon/ WWF-WWFin Congo Basin. www.wwf-congobasin.org $\$ cameroon.wwf in Cameroon/wwf in Congo Basin. Accessed 2 Sept 2019

27. Wolfe ND, Prosser AT, Carrt JK, Tamoufe U, Mpondi-Ngole E, Torimiro JN, LeBreton M, McCutchant F, Birx DL, Burke DS. Exposure to nonhuman primates in Cameroon. Emerg Infect Dis. 2004; 10 (12): 2094-2099.

28. Cameroon/African Wildlife Foundation. https://www.awf.org/country/Cameroon. Accessed 2 Sept 2019.

29. Abong-Mbang Health District. Rapport des activites Du $1^{\text {er }}$ Semestre 2014 dans le District de Sante D’Abong-Mbang. 2014.

30. Department of Homeland Security. Threat and Hazard Identification and Risk Assessment Guide: Comprehensive Preparedness Guide (CPG). First Edition, 2012. 
31. Pemunta NV. Factors Impeding Social Service Delivery among the Baka Pygmies of Cameroon. J Progress Hum Serv. 2019; DOI: 10.1080/10428232.2019.1581041

32. WHO. Ten threats to global health in 2019. 2019. https://www.who.int>emergencies. Accessed 2 Sept 2019.

33. Aurelie KK, Muloye M, Bona NF, Charles KM, Mawupemor AP, Shixue L. Historical review of Ebola outbreaks, Advances in Ebola Control, In: Okware SI, IntechOpen. 2017. DOI: 10.5772/intechopen.72660.

34. Coltart CEM, Lindsey B, Ghinai I, Johnson AM, Heymann DL. The Ebola outbreak, 2013-2016: old lessons for new epidemics. Philos Trans R Soc Lond B Biol Sci. 2017; 372(1721): 20160297

35. WHO. As Ebola cases reach 3000 in DRC, WHO calls on all partners to fulfill promises to communities. 2019. https://www.who.int/news-room/detail. Accessed Sept 22019.

36. Medicins Sans Frontier. DRC Ebola outbreak: Crisis update- August 2019. 2019. . Accessed Sept 5 2019.

37. Buli BG, Mayigane LN, Oketta JF, Soumouk1 A, Sandouno TE, Camara B, Toure MS, Conde A. Misconceptions about Ebola seriously affect the prevention efforts: KAP related to Ebola prevention and treatment in Kouroussa prefecture, Guinea. Pan Afri Med J. 2015; 22(Suppl 1): 11

38. Kaoje AU, Yahaya M, Sabir AA, Raji MO, Abdulmumin S, Mohammed AU. Awareness, knowledge, and misconceptions of Ebola virus disease among residents of a rural community in Sokoto, Northwest Nigeria. Ann Trop Med Public Health [serial online], 2016; 9:105-11.

39. Gidado S, Oladimeji AM, Roberts AA, Nguku P, Nwangwu IG, Waziri NE, Shuaib F, Oguntimehin O, Musa E, Nzuki C, Nasidi A, Adewuyi P, Daniel T-A, Olayinka A, Odubanjo O, Poggensee G. Public knowledge, perception and source of information on Ebola virus disease-Lagos, Nigeria; September, 2014. PLoS Currents. 7:ecurrents.outbreaks.0b805ca244d700a47d6a3713ef2d6db. 2015.

40. Jalloh MF, Bunnel R, Robinson S, Jalloh MB, Barry AM, Corker C, Sengeh P, VanSteelandt A, Li W, Dafae F, Diallo AA, Martel LD, Hersey S, Marston B, Morgan O, Redd JT. Assessments of Ebola knowledge, attitudes and practices in Forécariah, Guinea and Kambia, Sierra Leon, July-August 2015. Philos Trans R Soc Lond B Biol Sci. 2017; 372: 20160304

41. Kobayashi M, Beer KD, Bjork A, Chatham-Stephens K, Cherry CC, Arzoaquoi S, Frank W, Kumeh O, Sieka J, Yeiah J, Painter JF, Yoder JS, Flanney B, Mahoney F, Nyenswah TG. Community knowledge, attitudes and practices regarding Ebola virus disease-Five countries, Liberia, September-October, 2014. MMWR Morb Mortal Wkly Rep. 2015; 64 (26):714-718

42. Manguvo A, Mafuvadze $B$. The impact of traditional and religious practices on the spread of Ebola in West Africa: time for a strategic shift. Pan Afr Med J. 2015; 22(Suppl 1): 9

43. Gatherer D. The 2014 Ebola virus disease Outbreak in West Africa. J Gen Virol. 2014; 95:1619-24.

44. Gire SK, Goba A, Andersen KG. Genomic surveillance elucidates Ebola virus origin and transmission during the 2014 outbreak. Science. 2014; 345:1369-72. 
45. Paix MA, PovedaJd, Malvy D, Bailly C, Merlin M and Fleury HJ. Serological study of the virus responsible for hemorrhagic fever in an urban population of Cameroon. Bull Soc Pathol Exot Filiales. 1988; 81, 679-682.

46. Gonzalez JP, Josse R, Johnson ED, Merlin M, Georges AJ, Abandja A, Danyod M, Delaporte E, Dupont A, Ghogomu A, Kouka-Bemba D, Madelon MC, Sima A, Meunier DMY, Antibody prevalence against hemorrhagic fever viruses in randomized representative Central African populations. Res Virol (Annales de l'Institut Pasteur). 1989, 140, 319-331.

47. Phyhlala A. What future for the Baka? Indigenous peoples' rights and livelihood opportunities in South-East Cameroon; Report 13- International Work Group for Indigenous Affairs (IWGIA); Copenhagen-Denmark, Plan Finland and Plan Cameroon. 2012; 14-38.

\section{Tables}

Table 1: Baseline characteristics of study Population 


\begin{tabular}{|c|c|c|}
\hline Characteristic & Number $\left(\mathrm{N}^{\circ}\right)$ & Percentage (\%) \\
\hline \multicolumn{3}{|l|}{ Ethnic group } \\
\hline Baka & 347 & $68 \%$ \\
\hline Bantu & 163 & $32 \%$ \\
\hline \multicolumn{3}{|l|}{ Gender } \\
\hline Male & 253 & $49.6 \%$ \\
\hline Female & 257 & $50.4 \%$ \\
\hline \multicolumn{3}{|l|}{ Age } \\
\hline 18- 25 & 164 & $32.2 \%$ \\
\hline $26-36$ & 147 & $28.8 \%$ \\
\hline $37-47$ & 70 & $13.7 \%$ \\
\hline $48-58$ & 63 & $12.4 \%$ \\
\hline$>58$ & 66 & $12.9 \%$ \\
\hline \multicolumn{3}{|l|}{ Level of Education } \\
\hline No Education & 102 & $20.0 \%$ \\
\hline Primary & 320 & $62.7 \%$ \\
\hline Secondary & 80 & $15.7 \%$ \\
\hline Tertiary & 8 & $1.6 \%$ \\
\hline \multicolumn{3}{|l|}{ Marital Status } \\
\hline Single & 102 & $20.0 \%$ \\
\hline Married & 375 & $73.5 \%$ \\
\hline Widow & 33 & $6.5 \%$ \\
\hline \multicolumn{3}{|c|}{ Native/Non-native of Baka village } \\
\hline Natives & 492 & $96.5 \%$ \\
\hline Non-natives & 18 & $3.5 \%$ \\
\hline \multicolumn{3}{|l|}{ Number of children } \\
\hline (1-5) Children & 301 & $72.5 \%$ \\
\hline (6-10) Children & 95 & $22.9 \%$ \\
\hline$\geq 11$ Children & 19 & $4.5 \%$ \\
\hline \multicolumn{3}{|l|}{ Occupation } \\
\hline Hunter & 160 & $31.4 \%$ \\
\hline Farmer & 152 & $29.8 \%$ \\
\hline Both (Farmer and Hunter) & 99 & $19.4 \%$ \\
\hline Traditional healer & 19 & $3.7 \%$ \\
\hline Others & 80 & $15.7 \%$ \\
\hline
\end{tabular}

Table 2: Relationship of demographic characteristics of study participants and their awareness on Ebola 


\begin{tabular}{|c|c|c|c|c|c|c|c|c|}
\hline $\begin{array}{l}\text { Demographic } \\
\text { Characteristics }\end{array}$ & \multicolumn{2}{|c|}{$\begin{array}{l}\text { Have you ever } \\
\text { heard of Ebola } \\
510(100 \%)\end{array}$} & \multicolumn{2}{|c|}{$\begin{array}{l}\text { Knows what } \\
\text { causes/gives Ebola? } \\
425(83.3 \%)\end{array}$} & \multicolumn{4}{|c|}{$\begin{array}{l}\text { Believe Ebola can be transmitted from } \\
\text { one person to another } \\
425(83.3 \%)\end{array}$} \\
\hline \multirow[t]{2}{*}{ Total } & & $\begin{array}{l}\text { No } \\
N(\%)\end{array}$ & $\begin{array}{l}\text { Yes } \\
N(\%)\end{array}$ & & \multicolumn{2}{|c|}{$\begin{array}{l}\text { No Idea } \\
N(\%)\end{array}$} \\
\hline & $85(16.7)$ & $\begin{array}{l}425 \\
(83.3)\end{array}$ & $\begin{array}{l}191 \\
(44.9)\end{array}$ & $\begin{array}{l}234 \\
(55.1)\end{array}$ & $146(34.4)$ & $183(43.1)$ & \multicolumn{2}{|c|}{\begin{tabular}{|l}
$\mathrm{N}\left({ }^{\circ}\right)$ \\
$96(22.6)$
\end{tabular}} \\
\hline Ethnic group & \multicolumn{2}{|l|}{$P=0.116$} & \multicolumn{2}{|l|}{$P<0.05$} & \multicolumn{4}{|l|}{$P<0.05$} \\
\hline Baka & $64(12.5)$ & $\begin{array}{l}283 \\
(55.5)\end{array}$ & $\begin{array}{l}125 \\
(29.4)\end{array}$ & $\begin{array}{l}158 \\
(37.2)\end{array}$ & $72(16.9)$ & $142(33.4)$ & \multicolumn{2}{|c|}{$69(16.2)$} \\
\hline Bantu & $21(4.1)$ & $\begin{array}{l}142 \\
(27.8)\end{array}$ & $66(15.5)$ & $76(17.9)$ & $74(17.1)$ & $41(9.7)$ & \multicolumn{2}{|c|}{$27(6.4)$} \\
\hline Gender & \multicolumn{2}{|l|}{$P=0.251$} & \multicolumn{2}{|l|}{$P=0.199$} & \multicolumn{4}{|l|}{$P=0.087$} \\
\hline Male & \begin{tabular}{l|l}
47 & 2 \\
$(9.2)$ &
\end{tabular} & 206 (40.4) & $86(20.2)$ & $\begin{array}{l}120 \\
(28.2)\end{array}$ & $75(17.7)$ & $94(22.1)$ & \multicolumn{2}{|c|}{$37(8.7)$} \\
\hline Female & $\begin{array}{l}38 \\
(7.5)\end{array}$ & $219(42.9)$ & $\begin{array}{l}105 \\
(24.7)\end{array}$ & $\begin{array}{l}114 \\
(26.8)\end{array}$ & $71(16.7)$ & 89 (20.9) & \multicolumn{2}{|c|}{59 (13.9) } \\
\hline Age & \multicolumn{2}{|l|}{$P=0.170$} & \multicolumn{2}{|l|}{$P=0.744$} & \multicolumn{4}{|l|}{$P=0.236$} \\
\hline $15-25$ & \begin{tabular}{l|l}
26 & 1 \\
$(5.1)$ &
\end{tabular} & $8(27.1)$ & $\begin{array}{l}57 \\
(13.4)\end{array}$ & $\begin{array}{l}81 \\
(19.1)\end{array}$ & $35(8.2)$ & $68(16)$ & 35 & \\
\hline $26-36$ & $\begin{array}{l}26 \\
(5.1)\end{array}$ & $1(23.7)$ & $\begin{array}{l}57 \\
(13.4)\end{array}$ & $\begin{array}{l}64 \\
(15.1)\end{array}$ & 49 (11.5) & $44(10.4)$ & 28 & \\
\hline $37-47$ & $\begin{array}{l}11 \\
(2.2)\end{array}$ & (11.6) & $29(6.8)$ & $30(7.1)$ & $21(4.9)$ & $25(5.9)$ & 13 & \\
\hline $48-58$ & $\begin{array}{l}16 \\
(3.1)\end{array}$ & (9.2) & $23(5.4)$ & $24(5.7)$ & $20(9.7)$ & $17(4)$ & 10 & \\
\hline$>58$ & $\begin{array}{l}6 \\
(1.2)\end{array}$ & $(11.8)$ & $25(5.9)$ & $35(8.2)$ & $21(4.9)$ & $29(6.8)$ & 10 & \\
\hline Education & $P<0.05$ & & $P<0.05$ & & $P<0.05$ & & & \\
\hline No Education & $73(14.3)$ & $29(5.7)$ & $25(5.9)$ & 74 (17.4) & 55 (12.9) & $30(7$ & & $17(4)$ \\
\hline Primary & $10(2.0)$ & $\begin{array}{l}310 \\
(60.8)\end{array}$ & $96(22.9)$ & $\begin{array}{l}142 \\
(33.4)\end{array}$ & $82(19.3)$ & 110( & 5.9) & $35(8.2)$ \\
\hline Secondary & $2(0.4)$ & $\begin{array}{l}78 \\
(15.3)\end{array}$ & $70(16.5)$ & $10(2.4)$ & $9(2.1)$ & $35(8$. & & $44(10.4)$ \\
\hline Tertiary & $0(0)$ & $8(1.6)$ & $0(0)$ & $8(1.9)$ & $0(0)$ & $8(1.9$ & & $0(0)$ \\
\hline Occupation & $P<0.05$ & & $P<0.05$ & & $P<0.05$ & & & \\
\hline Hunter & $33(6.5)$ & $\begin{array}{r}129 \\
(25.3)\end{array}$ & $\begin{array}{l}61 \\
(14.4)\end{array}$ & $\begin{array}{l}50 \\
(11.8)\end{array}$ & $65(15.3)$ & $45(1$ & & $20(4.7)$ \\
\hline Farmer & $19(3.7)$ & $\begin{array}{r}133 \\
(26.1) \\
\end{array}$ & $\begin{array}{l}43 \\
(10.1)\end{array}$ & $\begin{array}{l}74 \\
(17.4)\end{array}$ & $50(11.8)$ & $43(1$ & & $30(7.1)$ \\
\hline $\begin{array}{l}\text { Both (hunter } \\
\text { and farmer) }\end{array}$ & $20(3.9)$ & $\begin{array}{r}79 \\
(15.5)\end{array}$ & $\begin{array}{l}66 \\
(15.5)\end{array}$ & $32(7.5)$ & $17(4)$ & $40(9$ & & $32(7.5)$ \\
\hline $\begin{array}{l}\text { Traditional } \\
\text { healer }\end{array}$ & $3(0.6)$ & $\begin{array}{r}16 \\
(3.1) \\
\end{array}$ & $1(0.2)$ & $18(4.2)$ & $5(1.2)$ & $14(3$ & & $0(0)$ \\
\hline Others & $10(2.0)$ & $\begin{array}{r}68 \\
(13.3)\end{array}$ & $20(4.7)$ & $60(14.1)$ & $9(2.1)$ & $41(9$ & & $14(3.3)$ \\
\hline
\end{tabular}


Figures

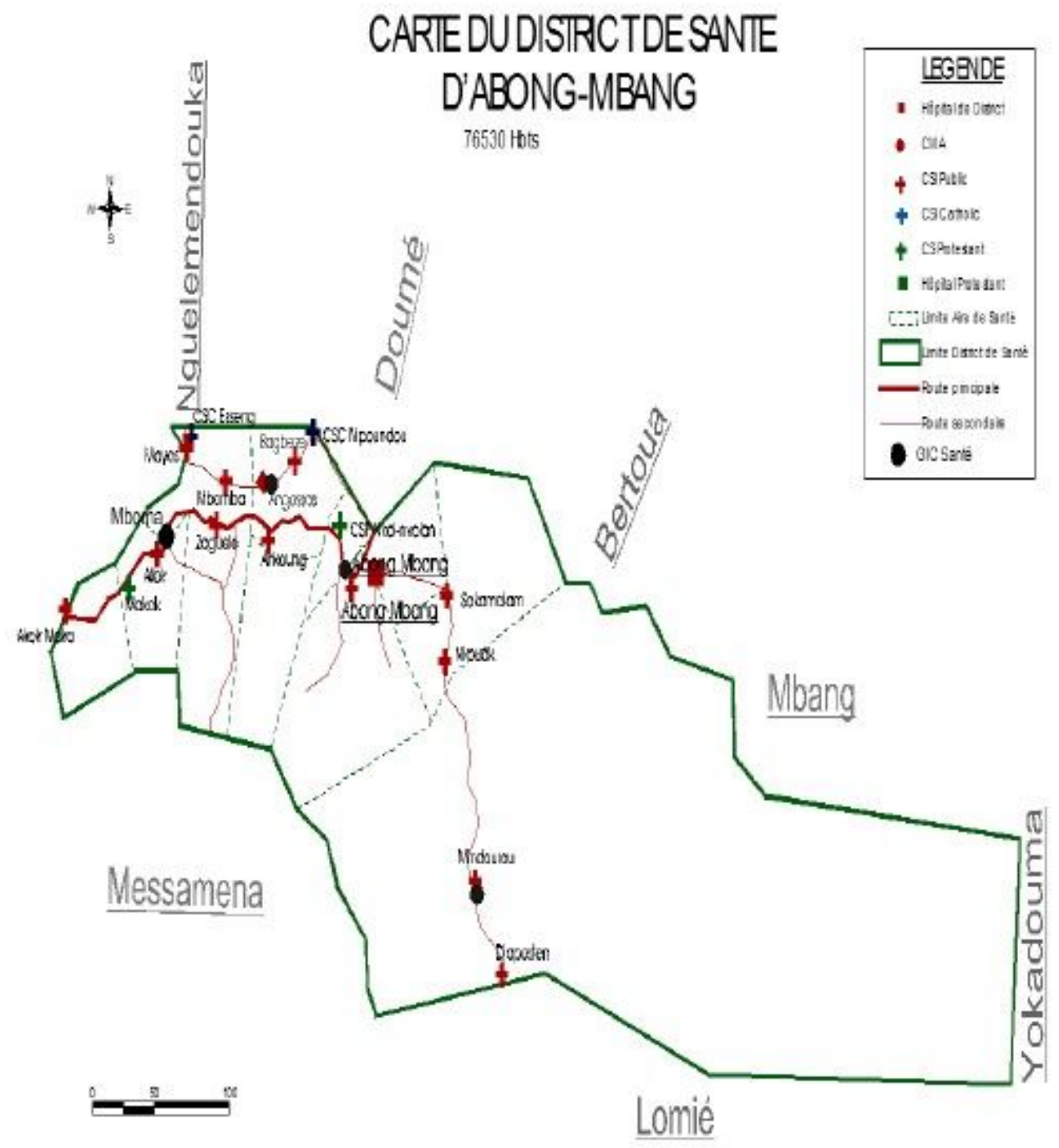

Figure 1 
Map of Abong-Mbang Health District showing various health areas Source: [29]
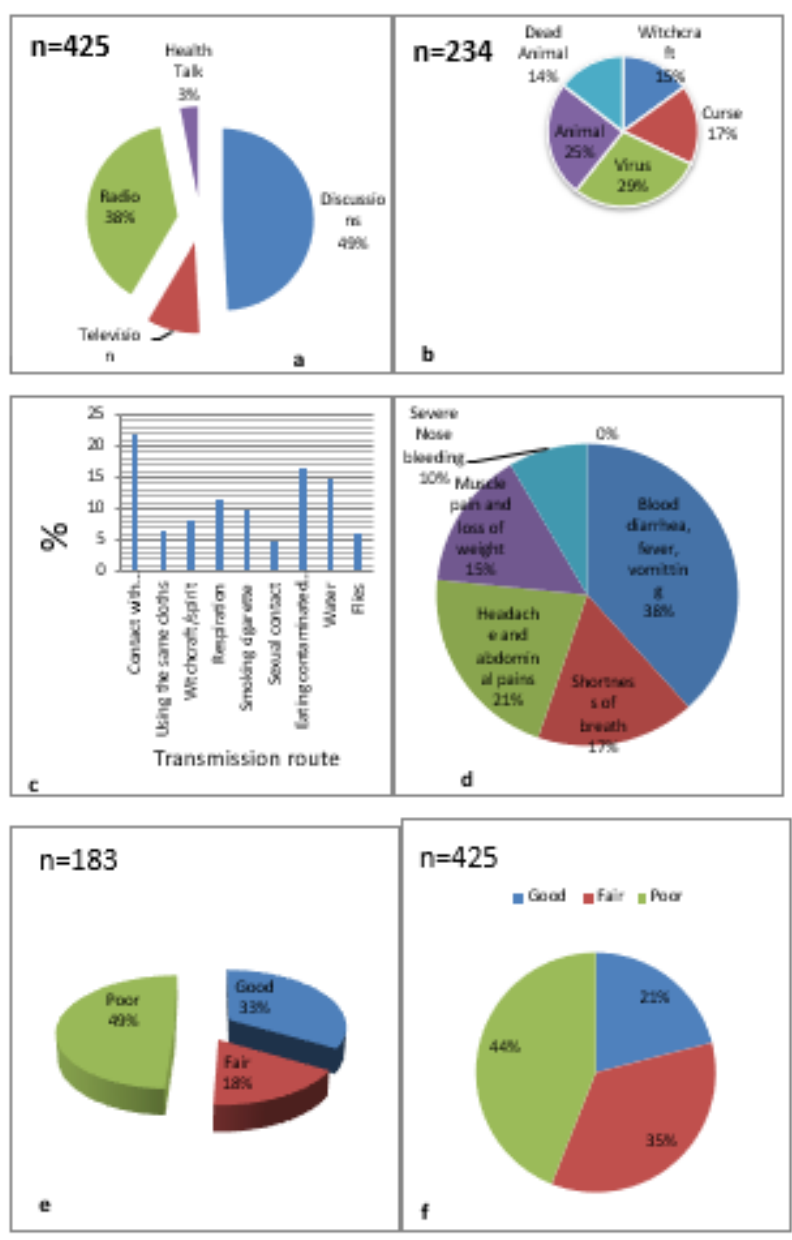

\section{Figure 2}

Participants' knowledge on EVD (a) Sources of information of study participants (b) Opinion on causes of EVD; (c) Modes of Transmission(d) Manifestations encountered by participants (e) Level of knowledge on means of EVD Transmission ( $f$ ) Level of knowledge of manifestations of Ebola 

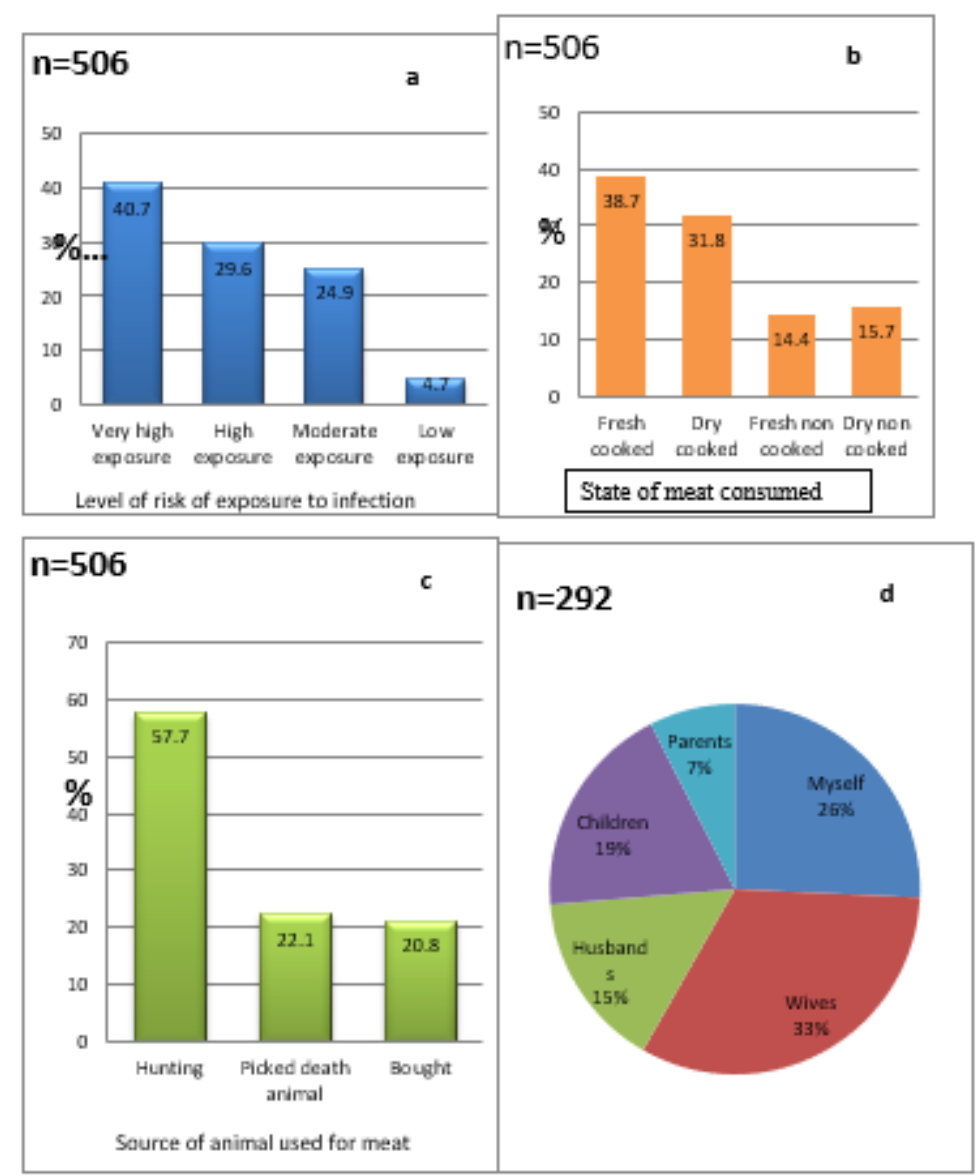

Figure 3

Feeding behaviour of participants: (a) Risk of exposure of participants to Ebola (b) State of meat consumed (c) Source of meat (d) Person preparing the meat 

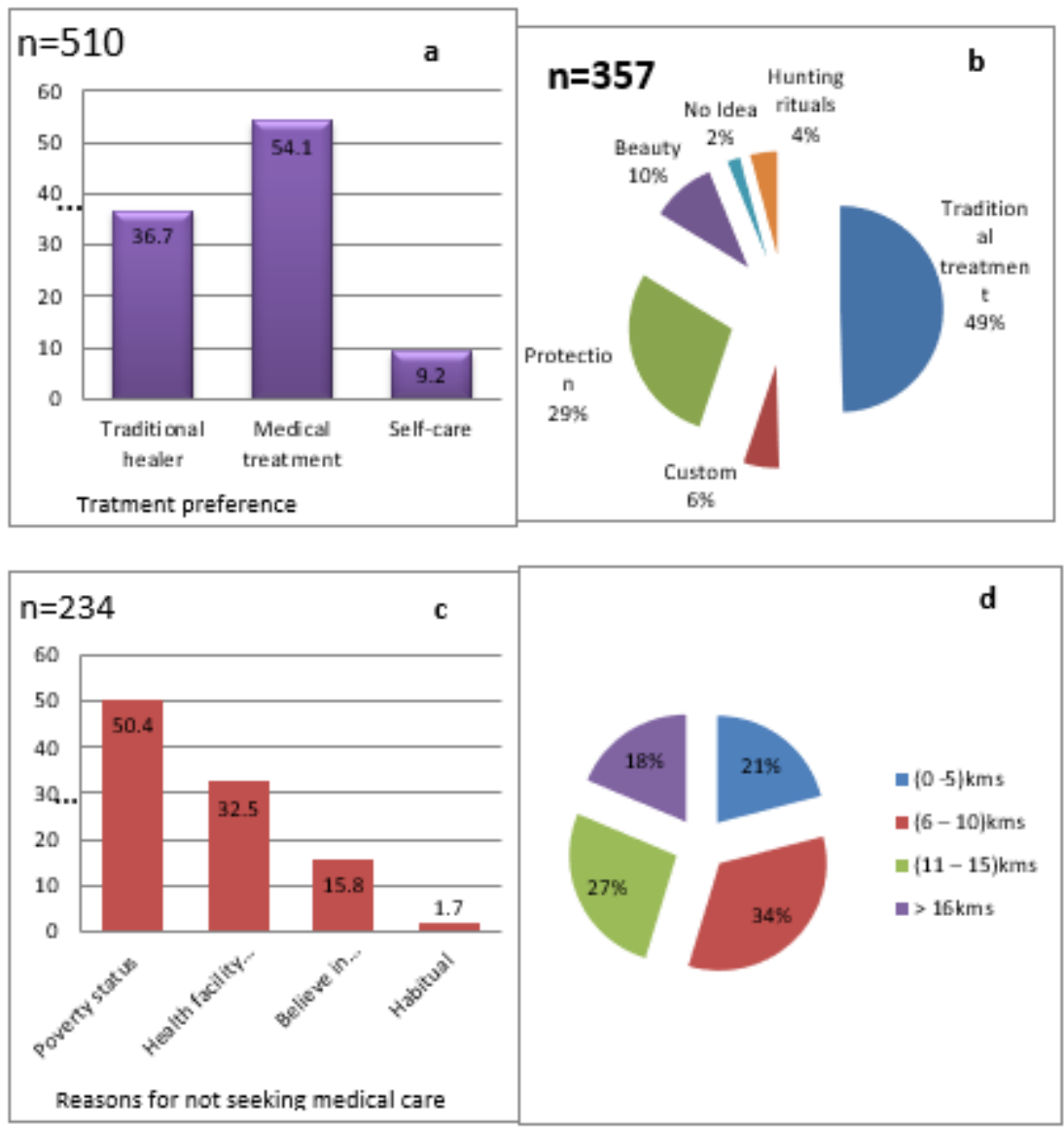

Figure 4

Health seeking behaviour of participants (a)Treatment preferences of study participants (b) Reasons for scarification (c) Reasons for not seeking medical care in the health facility (d) Distance to health facility from place of residence

\section{Supplementary Files}

This is a list of supplementary files associated with this preprint. Click to download.

- FinalEnglishquestionnaire1.docx

- Equations.docx 